\title{
Electronic Waste and Sustainability: Reflections on a Rising Global Challenge
}

Bipul Kumar

Indian Institute of Management, Indore

Kalyan Bhaskar

Indian Institute of Management, Lucknow

Follow this and additional works at: https://digitalcommons.uri.edu/mgdr

Part of the Anthropology Commons, Business Law, Public Responsibility, and Ethics Commons, Economics Commons, Environmental Studies Commons, Marketing Commons, Other Business

Commons, and the Sociology Commons

\section{Recommended Citation}

Kumar, Bipul and Bhaskar, Kalyan (2016) "Electronic Waste and Sustainability: Reflections on a Rising Global Challenge," Markets, Globalization \& Development Review. Vol. 1: No. 1, Article 5.

DOI: 10.23860/MGDR-2016-01-01-05

Available at: https://digitalcommons.uri.edu/mgdr/vol1/iss1/5

This Article is brought to you for free and open access by DigitalCommons@URI. It has been accepted for inclusion in Markets, Globalization \& Development Review by an authorized editor of DigitalCommons@URI. For more information, please contact digitalcommons-group@uri.edu. 
Electronic Waste and Sustainability: Reflections on a Rising Global Challenge

\section{Markets, Globalization \& Development Review}
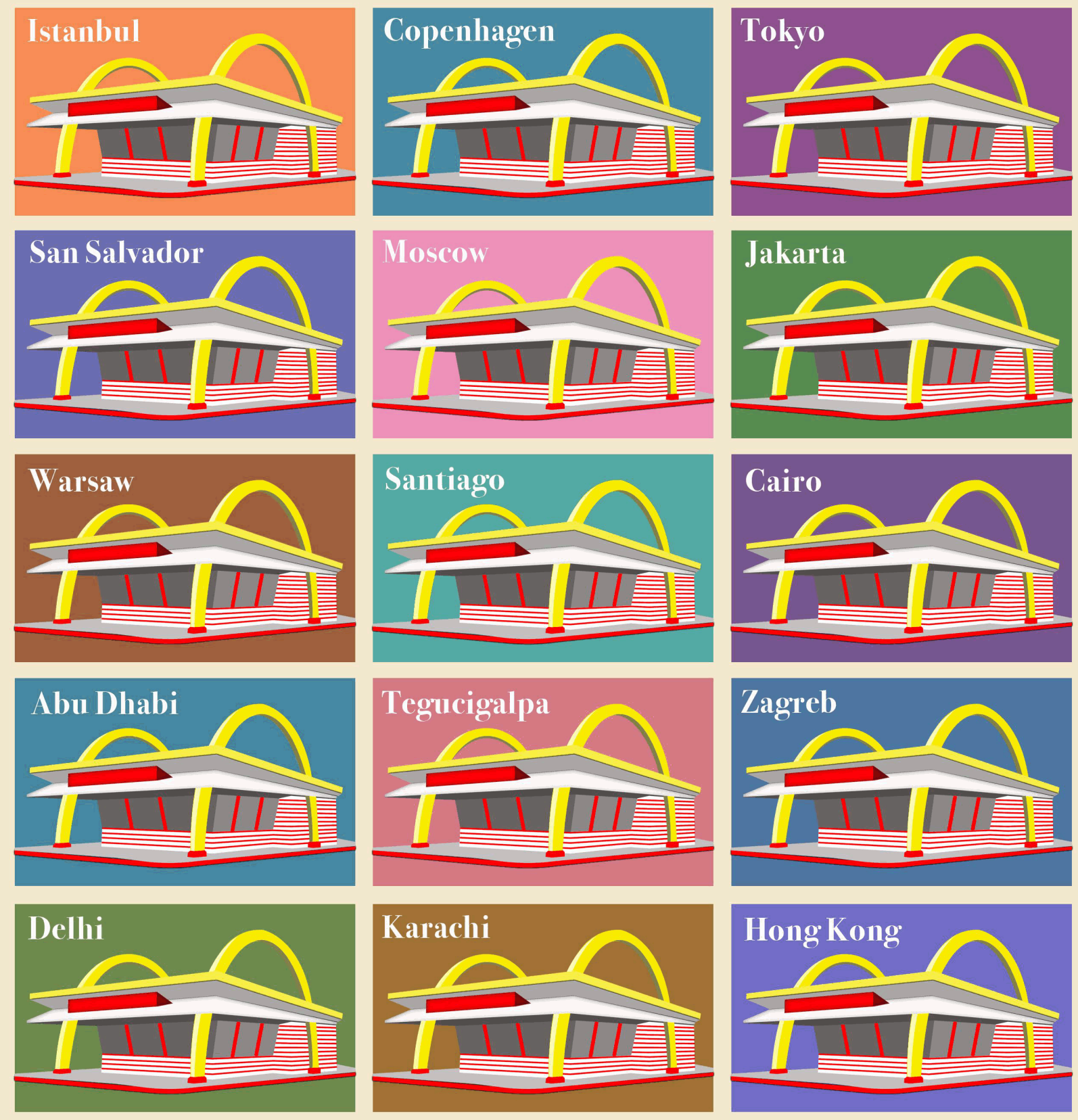

This article is available in Markets, Globalization \& Development Review: https://digitalcommons.uri.edu/mgdr/vol1/ 


\section{Electronic Waste and Sustainability: Reflections on a Rising Global Challenge}

\section{Introduction}

The world economy has gone through a massive transformation in the last two decades. The World Trade Organization (WTO) was formed in 1995 with the main aim to promote globalization and foster easier global movement of goods and services. Evidence suggests that the volume of global trade of goods and services has jumped manifold since then. The total volume of global trade has gone up from a little more than US\$6 trillion in 1995 to over US\$36 trillion in 2014 (IMF 2016). The pattern of trade has also undergone a change. Today the bulk of global trade happens between advanced economies and emerging economies, while in 1995 most global trade used to happen among the advanced economies. Among the three sectors of global economy, services sector continues to contribute the maximum to global economy and, with the rise of industries like information technology (IT) and financial services, has seen its share increase at the expense of industry and agriculture (Table 1).

Table 1: The Three Sectors of the Global Economy

\begin{tabular}{|l|l|l|}
\hline Sector & $\begin{array}{l}\text { Share in world } \\
\text { economy 1995 }\end{array}$ & $\begin{array}{l}\text { Share in world } \\
\text { economy 2014 }\end{array}$ \\
\hline Services & $58.5 \%$ & $68 \%$ \\
\hline Industry & $33.5 \%$ & $28 \%$ \\
\hline Agriculture & $8 \%$ & $4 \%$ \\
\hline
\end{tabular}

Another major development in this period has been the emergence of China as a global hub of manufacturing in various sectors such as metals, electronics and communications, and automobiles. Driven mainly by China, emerging market economies have contributed more than half of the global growth in the last 15 years (IMF 2016). While no industry sector has been left unaffected by these global developments, electronics and telecommunications industry is perhaps the industry that has witnessed the most significant and major shifts. Advent and growth of the internet, and advancements in communication technologies have led to a revolution the world over in the form of emergence of new Electrical and Electronic Equipment (EEE) like mobile phones and various handheld devices, and radical changes have taken place in existing EEE like computers and printers. One of the most iconic companies in this field, Apple, introduced 
the iPhone in 2007 and in nine years sold over 700 million iPhones in countries around the world (Reisinger 2015). Today Apple products are sold in more countries than there are members of the WTO (Linshi 2014; WTO Members and Observers 2015). Evolution of global trade and reduction of trade barriers have further allowed Apple to design its products in one country, manufacture phone and components in various other countries, and sell the finished products the world over with or without partnerships of local agencies (Minasians 2016). A similar story is reflected in consumer electronics industry where goods like televisions, computers, servers and other network equipment have witnessed significant technological advancements and sales boosts across regions of the world. A global economy increasingly driven by the services sector has continuous and growing requirements of EEE required for day-to-day business operations like computers, servers, and network switches. Rise in disposable incomes and changing consumer preferences have also ensured that the demand for EEE is also high from retail consumers like households.

The happy face of wide global availability - even in the economically poor parts of the world, of mobile phones and other affordable electronic devices - however, has a dark and foreboding side. A consequence of the growth in the sales of electrical and electronics equipment (EEE) has been the rise in volume of 'waste electrical and electronics equipment' (WEEE), more commonly known as electronic waste (e-waste). Technological and product innovations, rapidly declining consumer prices, evolving consumer preferences, and quicker obsolescence of products have been considered as some of the drivers of global e-waste growth (Khetriwal, Kraeuchi and Widmer 2009). Some of these, for example rapidly declining consumer prices, are in turn a consequence of, among other factors, increased globalization that has allowed companies in one country or region to reap benefits of economies of scale by producing for multiple regions or countries.

Annual global levels of e-waste have crossed 40 million metric tons mark and are fast approaching 50 million tons (MT) (Baldé et al. 2014). Ewaste is different from many other streams of waste like household waste: it contains several precious metals (e.g., gold, silver), rare earth metals (e.g., lanthanum, cerium), toxic metals (e.g., lead, lithium, and mercury), besides containing biodegradable materials like wood and nonbiodegradable materials like plastic (Mayers, France and Cowell 2005; Ministry of Environment and Forest 2008). It is because of the presence of toxic metals that dumping in the landfills, as is usually done with 
household waste in several parts of the world, is not a recommended option for e-waste.

The contribution to global e-waste volume and the resulting effects are not uniform across regions of the world. There is a wide disparity across the advanced and emerging regions of the world when it comes to quantities and patterns of generation of e-waste, as well as domestic ewaste legislation, and management of e-waste including practices by market actors. There are 7 billion people in the world reached by consumer electronic products but only 4 billion are covered by national legislation for e-waste, and not all those laws are enforced in all places (Baldé et al. 2014). Advanced economies in general have high per-capita generation of e-waste, legislation for e-waste, management of e-waste almost completely by the organized and formal sector, and several mechanisms like take-back schemes by market actors. In contrast developing countries, particularly the poorer one, tend to have low percapita generation of e-waste, limited or no legislation for e-waste, large presence of informal and unorganized sector for management of e-waste, and limited or no mechanisms for market actors to deal with e-waste. The size and scope of global e-waste problem is discussed in the next section.

\section{Size and Scope of Global E-Waste Problem}

Figures for past and current sales, in volume terms as well as in value terms, of electrical and electronic equipment (EEE) are available in the public domain at various levels (e.g., for a company, a country, a region, or the world). The main sources of these figures are reports of national governments and government agencies, annual reports published by the companies and economic and market databases of various firms. For ewaste, however, there are no official figures available for past or current global generation. One of the main reasons for that is the fact that inventory of e-waste has not been maintained in most parts of the world and even today many countries do not have such official inventory figures. For example, India does not yet have official inventory figures for domestic e-waste generation. There are, however, many country-specific and region-specific estimates available from various agencies worldwide.

One of the most recent global estimates of e-waste was carried out by United Nations University (UNU) (Baldé et al. 2014). According to these estimates, the global e-waste generation in 2014 was expected to be 41.8 million metric tons (MT), up from 33.8 MT in 2010, and projected to grow to $49.8 \mathrm{MT}$ by 2018 . The report also provides estimates for e-waste generation at regional level as shown in Table 2. 
Table 2: Global and Regional E-waste Estimates

\begin{tabular}{|l|l|l|l|}
\hline Region & $\begin{array}{l}\text { Population in } \\
\mathbf{2 0 1 4} \\
\text { (millions) }\end{array}$ & $\begin{array}{l}\text { E-waste } \\
\text { generation in } \\
\mathbf{2 0 1 4}(\mathbf{M T})\end{array}$ & $\begin{array}{l}\text { Per capita e-waste } \\
\text { generation in 2014 } \\
\text { (kg/person) }\end{array}$ \\
\hline Africa & 1156.6 & 1.9 & 1.7 \\
\hline Americas & 982.8 & 11.7 & 12.2 \\
\hline Asia & 4349.6 & 16 & 3.7 \\
\hline Europe & 738 & 11.6 & 15.6 \\
\hline Oceania & 38.8 & 0.6 & 15.2 \\
\hline World & 7265.8 & 41.8 & 5.9 \\
\hline
\end{tabular}

Source: Baldé et al. (2014); United Nations World Population Prospects (2015)

There are some key insights from the above table. The first is that there is a large difference in e-waste generation across regions. For example while Europe and Americas (North and South America) generate almost the same quantity of e-waste, Africa generates less than one-fifth of that. The second is that, there is large disparity across regions in terms of per capita e-waste generation. Africa has the lowest per capita e-waste generation followed by Asia while Europe and Oceania have the highest per capita generation of e-waste. On per capita basis, Europe, Oceania, and Americas generate more than double the average world figures. More than $75 \%$ of world's population resides in Asia and Africa but the two regions contribute only about $43 \%$ of world's annual e-waste quantities. Richer regions in general generate far more e-waste compared to the comparatively poorer parts of the world.

\section{E-waste and Challenges for Sustainability}

E-waste poses a sharply rising challenge to global sustainability. Before we foray deeper into this challenge, we need to understand the basic nuances of sustainability. We begin by discussing overarching phenomenon of sustainability from various points of view, and then turn to a discussion of the challenges of e-waste to sustainability from different perspectives. We then move on to discuss key implications for policymakers and the market.

\section{Sustainability and Sustainable Development}

Sustainability and sustainable development have been defined in multiple ways, using various approaches, but there is no single uniformly accepted definition that covers all aspects of various approaches. Hunt (2011) described sustainability in its entirety as the congregation of diverse 
activist groups who endeavor to experience and share goals, policies and ideologies which are common to them and have larger view for the betterment of the entire world. This common worldview (Bridges and Wilhelm 2008), shared by the diverse groups under this approach, keeps a concern for the futurity, equity, and needs/wants for all stakeholders in this society (Hunt 2011). While one stream of research has looked at the sustainability purely from environmental angle (Sharma and Henriques 2005; Shrivastava 1995), the other stream of researchers considered sustainability from the triple bottom line perspective (e.g., Bansal 2005; Gladwin, Kennelly and Krause 1995). Triple bottom line emphasizes on taking into account the environmental, social and economic aspect of sustainability (Elkington 1994).

Although sustainability is conceived primarily as a global phenomenon considered in an aggregate manner, the aggregation actually is built upon some elementary constituent bases. Firms and their businesses are one such major elementary base playing an important role in sustainable development of societies since they operate in an ecosystem of which society is an integral part. Researchers have also described the collaborative effort of all stakeholders - namely government, non-government organizations and businesses - as the precursors of sustainability leading towards the goal of sustainable development (Murray, Haynes and Hudson, 2010). All such elaborations point towards all stakeholders, including firms, to develop a long term perspective so far as sustainability is concerned. Firms which understand the long term orientation of their sustainability related endeavors are actually more successful. Many researchers have highlighted the ways in which firms have actually developed the business case for sustainability with a long term vision (Reed 2001; Salzmann, lonescu-Somers and Steger 2005). Over the years, people in the firms have started viewing sustainability as an integrated system containing elements from economic, social and environmental settings applied in a smooth manner to garner make larger business sense (Smith and Sharicz 2011).

According to one of the most widely accepted definition proposed by the Brundtland Commission (World Commission on Environment and Development 1987), sustainable development is "development that meets the needs of present without compromising the ability of future generation to meet their needs".

Closely connected to the above definition are the three common approaches that cover the basic essence of sustainability. These three approaches are 1) People, Profit, and Planet 2) Scarcity, Equity, and Pollution, and 3) Social, Economic, and Environmental. We aim to provide 
an overview of the global sustainability challenges arising from e-waste in light of all these aspects of sustainability. While there are studies which have looked at one or more aspects and processes of e-waste such as technology, policy instruments, management, and recycling techniques, there are limited studies using a sustainability centric approach to analyze e-waste.

\section{People-Planet-Profit and E-Waste}

The 'people-planet-profit' or the 3P approach follows the triple bottom line term coined by John Elkington in early 1990s (Elkington 1994). The triple bottom line and the 3P approach have been popular with many corporations since then. According to this accounting-focused approach, sustainability has three elements: one that deal with people (society), one that deal with the environment (earth), and one that deal with the profits (business). Corporations are expected to account not just for one P (profit) but for the other 2 Ps also (people and planet). Sustainability encompasses the three elements and the vital interfaces between each of the three. Let us look into e-waste from the point of view of each of the Ps more closely.

People: A major proportion of global e-waste is managed by the informal and unorganized sector (Baldé et al. 2014; Manomaivibool 2009). A number of small to medium scale organizations employing millions of people in many countries of the world, including women and children, are involved in managing e-waste generated domestically within a country as well as e-waste imported through largely illegal means (Manomaivibool and Vassanadumrongdee 2011; Manomaivibool 2009; Widmer et al. 2005; Zoeteman, Krikke and Venselaar 2010). The largely informal nature of these organizations means that they are mostly outside the ambit of various national regulations on employment, trade practices, and environment. As such there is often scant regard paid by these organizations for meeting existing national norms. People employed in these sectors come in contact with toxic metals and are exposed to their toxic fumes, all of which present grave occupational, environmental, and health hazards (Bandyopadhyay 2008; Manomaivibool 2009).

Planet: There are two main aspects related to planet in connection with e-waste. The first deals with the extraction of materials for production of EEE. The increased demand for EEE in the last two decades have led to increased extraction of rare earth metals, metals which are found in limited quantities in select regions of the world (Alonso et al. 2012). The continuous and unabated exploitation, in absence of proper recycling of such metals from e-waste, raises questions about the ability of mankind to 
keep extracting such rare earth metals for long. The second aspect deals with the unsafe and unscientific e-waste disposal practices being followed in many regions of the world. Many precious metals and rare earth metals are lost by the use of primitive practices like open hammering and burning in the informal sector. The presence of several toxic elements in e-waste further mean that such practices also end up causing damage to the local environment, including water bodies, air, and land.

Profit: There are two components of e-waste that have a vital interface with the tremendous value lost by not recycling e-waste - one being the loss of precious metals like gold and silver, and rare earth metals; and the other being the direct impact on human value degradation such as health hazards due to exposure of metals like lead and chromium. Traditionally, firms have kept their focus on basic buying behaviors of the consumers, which is mainly pivoted on the pre-consumption activities. Firms primarily focus on the attributes of the products to match the needs and wants of the consumers and hence their overall emphasis revolves around the issues like pricing, promotions, branding and so on. There is limited focus by the firms, so far, on the post-sales consumption behaviors of consumers which spans issues like faster obsolescence and engineered obsolescence. There is an equal lack of focus on postconsumption behavior comprising of vital issues like disposal of the used products, take-back mechanisms and systems for exchanging the used products.

\section{Scarcity-Equity-Pollution and E-Waste}

According to this ecology-focused approach, sustainability deals with scarcity (natural resources extracted from earth systems), equity (how those natural resources are distributed across regions and across people), and pollution (the damage to ecosystem because of activities involved in extracting, processing, and consumption of natural resources).

Scarcity: In the context of e-waste, it refers to varied availability of different natural resources used in the manufacturing of EEE. Several precious metals, rare earth metals, other toxic and nontoxic metals, and other materials like silica and wood are used in the manufacturing process. While some materials like wood are available in relative abundance, others like rare earth metals are available in finite quantities in the earth. Scarcity of such rare earth metals which are an important component in the manufacturing of not just EEE but for several applications in the clean tech sector, has serious considerations for sustainability. Existing industrial and market practices do not focus on the 
recovery, reuse, and recycling of materials from waste and instead focus on the extraction of virgin materials from earth.

Equity: There are issues of both inter-generational and intrageneration equity with e-waste. Over-extraction of rare earth metals for production of EEE and lack of focus on reuse and recycling of precious and rare earth metals raise question on the ability of mankind to keep producing EEE for future generations. The intra-generational equity concerns amplify; with the wide disparity in e-waste generation across regions, and the wide difference in practices of e-waste management among developed and developing economies. Within a region also, it is the rich that are the major consumers of EEE, but it is often the poor who have to manage e-waste, and - in case of several developing economies - it is the poor, working in the informal sector, who are exposed to numerous ill effects of handling e-waste.

Pollution: Environmental pollution occurs broadly in two instances. One during the mining and extraction processes of metals from underground reserves. The second is when e-waste is dealt in an unscientific manner. Water gets polluted when toxic metals from e waste are released to groundwater bodies or percolate to underground reserves in areas where e-waste is processed in unsafe and unscientific ways. Open burning of e-waste also releases several toxic fumes in the air that contributes to local air pollution.

\section{Social-Economic-Environmental and E-waste}

According to this development-centric approach, sustainable development has three aspects: social, economic, and environmental (Basiago 1999). Development, according to this approach, is sustainable only when it considers the effect on social aspects, environmental aspects, and the economic aspects.

Social: Society is the biggest stakeholder of a business ecosystem, whether as consumers or as employees. The entire cycle of consumption - right from attitude formation in a pre-consumption scenario to consumption stage and finally the post consumption behavior - has great impact on the society. All such behaviors and especially the postconsumption behaviors in the case of electronic products has impacts on some important stakeholders of the society, such as women and children, in terms of their safety and health since they are the part of the workforce dealing with such waste in most of the developing countries. In case of electronic products, the changing consumer preferences and declining product lifespan are issues which require the society to have a relook at such consumption. The shorter the product lifespan, the earlier the product 
is likely to be categorized as e-waste and the faster will be the growth in the volume of e-waste.

Economic: Today the market is flooded with a variety of electronic products that are touching upon the market economy in increasingly bigger ways. Many electronic products have a hardware aspect and a software aspect. For example in case of mobile phones, there are frequent upgrades in the operating system and numerous third-party applications. The high frequency of software upgrades often means the hardware is incompatible with the latest software. While this scenario - where changing the hardware becomes or is made to appear necessary not because of any malfunctioning of the hardware but because of the incompatibility issues - may be economically lucrative for the software developers and hardware makers, the consequences for the overall economy, considering the economic impacts of e-waste, can be severe. In pursuit of economic growth, companies may want consumers to keep buying new EEE and discarding old EEE. But the economic costs of managing the ever increasing e-waste will soon become too much to ignore for the society, governments, and for businesses themselves.

Environmental: The environment perhaps is the worst impacted entity due to handling of e-waste. All aspects of the environment - such as air, water and land - are affected adversely due to handling of e-waste in unscientific ways. The environment is affected when virgin materials are extracted from the earth for production of EEE. The environment is also affected when used materials are not recovered and reused and instead find their way back into the environment in degraded forms: in landfills or in form of toxic gases generated by the burning of materials.

\section{Discussion and Preliminary Policy Implications}

The challenges arising from the growing volume and current state of management of e-waste are not just for the local environment but for sustainability on a much wider scale. Traditionally businesses have limited their attention to manufacturing and sales, what we refer to as preconsumption processes. What happens during post-consumption processes - i.e., after sales, during consumption of the products, after the product has been discarded by the consumer and at the end of product lifecycle - have largely been ignored by businesses. In case of EEE and e-waste, because of the nature of these products and the presence of various toxic and nontoxic materials, existing approaches of businesses need to be rethought and revamped. In the short term, the dangers may be more for the environment and society, but in the long term the economic effects can be severe for the corporations themselves. The 
adverse economic impacts could take many forms: foregone costreduction potential due to lack of recycling; as well as other approaches to maximize recovery, reuse, and recycling. A relatively new approach, circular economy, advocates the benefits of recycling used materials and by-products of industrial processes (Andersen 2007). This could be one of the ways to address such economic impacts.

The economic impacts could also be in terms of consumer demand and movements for companies and products that are and seen as sustainable. It also has overall implications for sustainable and green supply chain initiatives.

Absence of market mechanisms to deal with e-waste in an environmentally sound and safe manner have been behind the several legislations on e-waste introduced in various countries. One of the most common and popular policy instruments has been that of extended producer responsibility (EPR) (Khetriwal et al. 2009; Manomaivibool and Vassanadumrongdee 2011; Ozdemir, Denizel and Guide 2012). According to EPR, the responsibilities of companies extend till safe disposal of endof-lifecycle products. The increasing prevalence of EPR points towards the need for businesses to work with the governments and society to jointly address the sustainability challenges arising due to e-waste. Businesses have reasons, the resources as well as the potential to take a leadership position in stewarding the cause of responsible e-waste management.

\section{Concluding Remarks}

Ayres (1989) discussed the connection between industries and the ecosystem surrounding them by terming the connection as industrial metabolism'. Industrial ecosystem was equated by him with a living organism which consumes energy and material resource for producing desired as well as undesired externalities like waste. It is pertinent in the whole discussion that if this industry organism keeps on consuming more and more resources than the regeneration capacity of the ecosystem - and also emits more and more waste - then this ecological sink would no longer be in a position to absorb the externalities and the whole system would turn into an out-of-control unsustainable system. Hence, fulcrum of the sustainability needs to be balanced and fine-tuned - keeping the monster of e-waste generation in check - for the larger benefit of societies and citizens of world. 


\section{References}

Alonso, Elisa, Andrew M. Sherman, Timothy J. Wallington, Mark P. Everson, Frank R. Field, Richard Roth, and Randolph E. Kirchain (2012), "Evaluating rare earth element availability: A case with revolutionary demand from clean technologies", Environmental Science and Technology, 46(6), 3406-3414.

Andersen, Mikael Skou (2007), "An introductory note on the environmental economics of the circular economy", Sustainability Science, 2(1), 133-140.

Ayres, Robert U (1989), "Industrial metabolism," in Technology and Environment, Pp. 23-49, Washington, DC: National Academy Press.

Baldé, C. P., F. Wang, R. Kuehr, and J. Huisman (2014), "The Global EWaste Monitor: Quantities, Flows and Resources", (accessed on: July 2, 2016), [available at https://i.unu.edu/media/unu.edu/news/52624/UNU-1 stGlobal-EWaste-Monitor-2014-small.pdf]

Bandyopadhyay, Amitava (2008), "Indian Initiatives on E-Waste Management-A Critical Review", Environmental Engineering Science, 25(10), 1507-1526.

Basiago, Andrew D. (1998), "Economic, social, and environmental sustainability in development theory and urban planning practice" Environmentalist, 19(2), 145-161.

Elkington, John (1994), "Towards the sustainable corporation: Win-win-win business strategies for sustainable development", California Management Review, 36(2), 90-100.

IMF (2016), "The growing importance of financial spillovers from emerging market economies", Global Financial Stability Report (Vol. April) (accessed on: July 4, 2016), [available at http://www.imf.org/external/pubs/ft/gfsr/2016/01/pdf/c2.pdf]

Khetriwal, Deepali Sinha, Philipp Kraeuchi, and Rolf Widmer (2009), "Producer responsibility for e-waste management: key issues for consideration-learning from the Swiss experience", Journal of Environmental Management, 90(1), 153-165.

Linshi, Jack (2014), "Why U.S. Sanctions Mean Some Countries Don't Get Any iPhones", (accessed on: July 4, 2016), [available at http://time.com/3502453/apple-iphone-sanction-tech/] 
Manomaivibool, Panate (2009), "Extended producer responsibility in a non-OECD context: The management of waste electrical and electronic equipment in India", Resources, Conservation and Recycling, 53(3), 136-144.

Manomaivibool, Panate, and Sujitra Vassanadumrongdee (2011), "Extended producer responsibility in Thailand", Journal of Industrial Ecology, 15(2), 185-205.

Mayers, C. Kieren, Chris M. France, and Sarah J. Cowell (2005), "Extended producer responsibility for waste electronics: An example of printer recycling in the United Kingdom", Journal of Industrial Ecology, 9(3), 169-189.

Minasians, C. (2016), "Where are the iPhone, iPad and Mac designed, made and assembled?", (accessed on: July 1, 2016), [available at http://www.macworld.co.uk/feature/apple/are-apple-products-trulydesigned-in-california-made-in-china-iphonese-3633832/]

Ministry of Environment and Forest (2008), "Guidelines for Environmentally Sound Management of E-Waste", (accessed on: July 2, 2016), [available at http://www.moef.nic.in/sites/default/files/guidelines-e-waste.pdf ]

Özdemir, Öznur, Meltem Denizel, and V. Daniel R. Guide (2012), "Recovery decisions of a producer in a legislative disposal fee environment", European Journal of Operational Research, 216(2), 293-300.

Reed, Donald J. (2001), "Stalking the elusive business case for corporate responsibility", World Resources Institute.

Reisinger, D. (2015), "Apple by the numbers", (accessed on: June 30, 2016), [available at http://www.cnet.com/news/apple-by-thenumbers-453-retail-stores-worldwide-120m-customers/]

Salzmann, Oliver, Aileen Ionescu-Somers, and Ulrich Steger (2005), "The business case for corporate sustainability: literature review and research options", European Management Journal, 23(1), 27-36.

Sharma, Sanjay, and Irene Henriques (2005), "Stakeholder influences on sustainability practices in the Canadian forest products industry", Strategic Management Journal, 26(2), 159-180.

Shrivastava, Paul (1995), "Industrial/environmental crises and corporate social responsibility", The Journal of Socio-Economics, 24(1), 211-227. 
Smith, Peter AC, and Carol Sharicz (2011), "The shift needed for sustainability", The Learning Organization, 18(1), 73-86.

United Nations World Population Prospects (2015), (accessed on: June 30, 2016), [available at https://esa.un.org/unpd/wpp/Download/Standard/Population/]

Widmer, Rolf, Heidi Oswald-Krapf, Deepali Sinha-Khetriwal, Max Schnellmann, and Heinz Böni (2005), "Global perspectives on ewaste", Environmental Impact Assessment Review, 25(5), 436-458.

World Commission on Environment and Development (1987), "Our Common Future", Oxford: Oxford University Press.

WTO Members and Observers (2015), (accessed on: July 1, 2016), [available at https://www.wto.org/english/thewto_e/whatis_e/tif_e/org6_e.htm ]

Zoeteman, Bastiaan CJ, Harold R. Krikke, and Jan Venselaar (2010), "Handling WEEE waste flows: on the effectiveness of producer responsibility in a globalizing world", The International Journal of Advanced Manufacturing Technology, 47(5-8), 415-436. 